\title{
Creativity in Brazilian Education: Review of a Decade of Literature
}

Juliana Berg ${ }^{1}$, Carla Luciane Blum Vestena ${ }^{2}$, Cristina Costa-Lobo ${ }^{3}$

${ }^{1}$ CaPes Scholarship, Education at the Federal University of Paraná, Master's in

Education from the State University of the Center-West. Educational Psychology

Laboratory (LAPE), Irati, Brazil

${ }^{2}$ Scholarship productivity of F.A. Education and the Graduate Education Programs of the Federal University of Paraná and State University of the Center-West,

Educational Psychology Laboratory (LAPE), Guarapuava, Brazil

${ }^{3}$ Psychology, the UNESCO Chair in Youth, Education and Society, the Fafe Institute for Higher Studies, UNIFACS-Bahia and State University of the Center-West, Porto, Portugal

Copyright (c) 2020 by author(s) and Scientific Research Publishing Inc.

This work is licensed under the Creative Commons Attribution International License (CC BY 4.0).

\section{ABSTRACT}

The present study resulted from the analysis of a large array of investigative products focused on creativity in higher education. A systematic review of studies between 2008 and 2018 found 27 theses published by doctoral programs in the specific field of education. Twentyfive Brazilian scientific databases were analyzed using a qualitative approach aimed at mapping creativity in higher education, demonstrating longitudinally how, when, who and with what purposes creativity has been the object of study. The most widely used approach was qualitative, with a predominance of case studies, the majority of which described creativity as a learning strategy or one that seeks learning solutions; a smaller number of doctoral theses viewed creativity as cognitively developed and intrinsic to the student. For this reason, the results suggest a possible lag in terms of understanding creativity as a way to significantly strengthen learning and a basic structure in the development of critical thinking and problem solving.

Keywords:

Creativity, Systematic Review, Higher Education, Brazil

\section{Introduction}

The current demand for education characterized by autonomy, purposefulness and critical thinking has galvanized international organizations such as UNESCO, whose Global Education 2030 Agenda supports initiatives that develop the human skills essential to meeting global objectives linked directly to solutions that ensure overall quality of life, perceived by the populations of some countries as

unsatisfactory (Lubart, 2007; Sternberg, 2000; UNESCO, 2017).

The global dynamic and synergy for change generates new life perspectives and has led to advances in a number of countries and their educational systems, which have presented innovative models and invested in creative thinking as a path to greater human development (Alencar \& Fleith, 2003). 
To this end, this study presents a systematic analysis by review that demonstrates the understanding of how scientists from postgraduate programs in Education in Brazil is researching the theme of creativity and what is its impact on current education. It also seeks to analyze whether such research is engaged with this global view, seeking to innovate the current educational system.

In Brazil, the education system displays worrisome deficiencies, caused primarily by the lack of investment in teacher training and school administrators, as well as the resistance of the professionals themselves to innovation, because they are unqualified, uncommitted, poorly motivated or use outdated teaching methods (Alencar \& Fleith, 2003; OCDE, 2016).

According to the Anisio Teixeira National Institute for Educational Studies and Research (INEP) (2017), the Basic Education Development Index (IDEB) shows that only the first grades of elementary school achieved the goals established by the Ministry of Education (MEC). The index monitors basic reading and writing skills, as well as logical-mathematical reasoning for each stage of child development and learning. It is calculated based on data obtained from the school census and average performance in the Basic Education Assessment System (SAEB).

Brazil ranks among the worst in the Programme for International Student Assessment (PISA), created by the Organization for Economic Cooperation and Development (OECD), whose aim is to "produce indicators that contribute to the discussion of quality education" subsidizing policies to improve teaching through "compared assessment of 15-year-old students enrolled in grade 7" (OCDE, 2016). Despite characterizing Brazilian education as inadequate, neither PISA nor IDEB surveys the entire country, thereby disregarding important analysis variables. In this respect, an education system is conceived to be dynamic and non-static, reflecting the cultures and societies to which it belongs.

Thus, by combining these assessment indices with variables such as the perceptions of teachers, students and professionals, in addition to analyzing scientific research and the current social phenomenon of accelerated communication, which is making the present increasingly fleeting and the future ever closer, we concluded that the Brazilian education system is causing significant social delays in learning, possibly condemning future Brazilian education to stagnation (Alencar \& Fleith, 2003; Vergara \& Vieira, 2005).

Simple, repetitive solutions can no longer be accepted; rather, complex thinking capable of analyzing problems and conflicts in different domains is required, in addition to the ability to anticipate, understand and assesses the near future, negotiate guidelines and values, collectively develop innovative actions, collaborate, understand, respect, be aware of and deal with conflicts, as well as question and assume a position based on self-knowledge about the social role occupied (UNESCO, 2017). As such, assessing and understanding creativity is no longer a new issue; it is addressed globally in the socioeconomic, cognitive, socioemotional and behavioral fields (UNESCO, 2017).

In this respect, developing creative education involves work, dedication, engagement and assessment. However, its value, usefulness and acceptance cannot be restricted only to the utilitarian-reductionist logic of purpose and function for a product or idea, standardizing and establishing tensions that compromise the creative process. It is important to remember that creativity goes beyond this, and that the individual must also be taken into account (Costa-Lobo et al., 2017a). Creating involves imaginative, inventive, innovative, intuitive, inspirational and original thought processes. It is a complex, multifaceted phenomenon with dynamic interaction between elements related to people, the environment, culture, society and the opportunity of self-expression (Costa-Lobo et al., 2017c; Csikszentmihayi, 1996). 
The current concept of creativity in education calls for a multifaceted approach that combines "relevant elements such as intellectual capacity and personality traits, as well as the environmental context" (Lubart, 2007: p. 17). This complex approach involves both creative people and creative and cooperative groups, or cognitive, conative, emotional and environmental factors that interact and are often formed by the logic contained in feedback systems in the social and/or cultural field (Alencar \& Fleith, 2003; Csikszentmihayi, 1996; Sternberg, 2000; Lubart, 2007).

Thus, when a creative moment occurs, the cognition of people open to creativity acts in information and knowledge analysis systems, locating, coding and observing evidence, regrouping data and phenomena, assessing various possibilities and making task decisions flexible (Alencar \& Fleith, 2003; Costa-Lobo et al., 2017a; Lubart, 2007).

Conative factors related to habits and behavior associated with personality, cognition and motivation drive perseverance, tolerance, flexibility, cooperation and individuality. The ability to assume risks, intrinsic and extrinsic motivation and emotions act systematically in this complex network so that positive emotional states favor or inhibit creative performance (Alencar \& Fleith, 2003; Amabile, 1996; Bahia, 2014; Costa-Lobo et al., 2017b; Csikszentmihayi, 1996; Lubart, 2007). This context joins these factors, interfering as a judge in decision making and/or as a regulator that standardizes acceptability of creative action. The family, school and community also have a direct influence, and in repressive or very liberal environments, creativity is compromised. By contrast, settings that establish limits while being flexible in terms of rules and habits are stimulating and supportive of ideas (Alencar \& Fleith, 2003; Amabile, 1996; Csikszentmihayi, 1996; Gardner, 1995; Lubart, 2007; Sternberg, 2000). Thus, spaces that offer experiences and objects that represent individual and/or collective realities, with the possibility of intentionally or spontaneously stimulating the imagination, illusion or fantasy, even with partially defined limits, are dialogical contexts or accessible symbolic fields where creative people are allowed to exchange ideas and create (Csikszentmihayi, 1996; Morin, 2000).

As new challenges arise, creativity generates benefits such as rethinking collaboration and recreating practices, prompting the demand for an educational context that provides even more instruction, autonomy and critical thinking, encouraging inquiry and improving quality (Costa-Lobo et al., 2016; Costa-Lobo \& Cabrera, 2017c).

Whether society and the State are willing to invest in creative policies, measures and dialogue in Brazilian education, as has occurred in other countries, or encourage the development of skills that promote post-modern thinking, remains to be seen. However, countries that invested in such changes in their education system, perceiving how creativity alters the way of thinking, are at the forefront of education and social relations (UNESCO, 2017).

In this respect, the aim of this study was to determine a) how Brazil researches and views creativity in education, b) the main scientific problems, c) the methods used and theoretical lines adopted, d) which Brazilian regions investigated creativity in education and e) which creativity concept was established. To that end, a systematic review was conducted to assess a decade of Brazilian research into creativity.

\section{Method}

This study presents a summary of the scientific process related to creativity in education using a systematic review of the literature. This scientific method of surveying and analyzing studies is widely used in the fields of Education, Medicine and Social Sciences, since there are large amounts of data and sources of information available. Systematic reviews are considered the most suitable means of 
underscoring good practices in a number of areas, and the most comprehensive in making the sector diagnosis proposed here.

Cochrane (1972) reports the need to use systematic literature reviews and criticize medical practices, with a view to bridging gaps such as the lack of scientific evidence in treatments, interventions, tests and other medical procedures. Systematic reviews use a set of procedures and techniques with scientific rigor, in order to achieve better results, minimize errors and reduce the main researcher's bias, providing high-quality scientific evidence.

The definition of a scientific literature review followed here describes the process as collecting, knowing, understanding, analyzing, summarizing and assessing a set of scientific studies aimed at creating the state of the art in a particular research topic (Levy \& Ellis, 2006).

Over the years, several institutions have created and consolidated suggestions to develop a systematic model for a literature review. There are two different, but complementary theoretical publications: the Cochrane Handbook (1972) and CDR Report. Although other methods are applied, such as PRISMA, the first two are frequently used in studies. According to the Cochrane Handbook (1972), there are seven stages in a literature review: 1) formulation of the research question; 2) study location and selection in indexed databases; 3) critical assessment of studies; 4) data collection; 5) data analysis and presentation; 6) data interpretation; and 7) review improvement and up-date.

The CDR Review, in turn, presents a protocol for conducting a systematic literature review consisting of three phases and ten stages. In the first phase (review planning), there are three stages: identifying the need for the review, preparing a proposal for a systematic review and developing a review project. The second phase contains five stages: identification in the literature, study selection, assessment of study quality, data extraction, and monitoring data progress and synthesis. The third phase, involving the presentation and dissemination of a report, consists of two stages: report and recommendations and evidence of the practice.

Since both publications (the Cochrane Handbook and CDR Report) are similar, a number of authors decided to combine them into a third method, based on consensus among researchers. To better understand the scenario proposed in the present study, one must reflect critically on the different contributions of researchers to the models developed for systematic reviews.

Two theoretical models can be emphasized. The first describes the systematic review as consisting of three main phases. In the first phase, all preliminary information that will be analyzed is collected, such as classic studies in the field of research, books and texts that discuss the topic and reference documents indicated by specialists. The second phase contains six stages: knowing the literature; understanding the literature; applying the review; compiling the results; analyzing the results; and assessing the results. Finally, in the third phase, the results are summarized.

This model reinforces the need for the systematic literature review in cycles during the six stages, as follows: knowing the literature; understanding the literature; conducting the review; analyzing the results; preparing a summary of the results; and assessing the results obtained. Thus, when knowledge of the topic increases, the cycles are executed more efficiently. The cycle, in turn, will be repeated as many times as necessary, in order to reach the goals established for the bibliographic review.

The model proposed involves planning, execution and analysis of results. However, in contrast to Levy and Ellis (2006), it does not emphasize the need for interactive research, analysis and comprehension cycles. Rather, it monitors the learning and knowledge acquired by researchers during studies, reading and text comprehension. 
In the planning phase, the objectives of the systematic review are established and the protocol developed, which describes the central research question, objectives, keywords, research sequences and execution method. If the protocol is approved by all the researchers, the second phase (execution) initiates. During the execution phase, the primary studies are identified, selected and assessed, considering the inclusion and exclusion criteria established in the protocol. After the primary studies are selected, the data are extracted and compiled during the result analysis phase. It is important to underscore that the results should be evaluated during the first and second phases because the implementation phase is repeated in the event of negative outcomes.

In this review, we opted for a mixed approach, combining systematic review methods, as outlined above. The study lasted sixteen months (November 2017 to February 2019). In the first stage, we established the research question, objectives, primary sources, search strings, inclusion and exclusion criteria, qualification categories, method and schedule (Esteves, et al., 2017; Sampaio \& Mancini, 2007). Next, preliminary studies were selected consisting of defended theses, available in twenty-five Brazilain government and university databases, as follows: Pontifical Catholic University of Rio Grande do Sul (PUC-RS), São Paulo (PUC-SP) and Campinas (PUC-Campinas); Brazilian Digital Library of Theses and Dissertations (BDTD); Coordination for the Improvement of Higher Education Personnel/Ministry of Education (CaPes/MEC); Public Domain (DP); University of Brasilia (UNB); University of Campinas (UNICAMP); University of São Paulo (USP); State São Paulo State University (UNESP); Federal University of Bahia (UFBA); Federal University of Paraíba (UFPB); Federal University of Goiás (UFGO); Federal University of Minas Gerais (UFMG); Federal University of Pernambuco (UFPE); Federal University of Santa Catarina (UFSC); Federal University of São Carlos (UFSCAR); Federal University of São Paulo (UNIFESP); Federal University of Amazonas (UFAM); Federal University of Maranhão (UFMA); Federal University of Mato Grosso (UFMT); Federal University of Pará (UFPA); Federal University of Paraná (UFPR); Federal University of Rio de Janeiro (UFRJ); and Federal University of Rio Grande do Sul (UFRGS). A primary data source and the search string "creativity" were used in the title, keywords or abstract. In the second phase, the results were surveyed, read and analyzed, in addition to documenting the studies (Esteves, et al., 2017; Sampaio \& Mancini, 2007).

The first filter located what was being searched for in the title; next, the abstract, introduction and conclusion were read and when the second filter was inadequate, the third filter involved reading the entire thesis. Only after the studies were classified were they compared for frequency in order to quantify and determine the type of research conducted, mapping productivity in terms of creativity (Esteves, et al., 2017; Sampaio \& Mancini, 2007).

Documenting the information obtained helped in the theoretical support of the topic, cataloging and the storing of texts. The third stage consisted of a bibliographic analysis and summary of results organized in an Excel spreadsheet, as well as conducting qualitative data analysis. Excel was selected due to the low number of studies found in this stage.

Inclusion criteria were theses published in Portuguese between 2008 and 2018, indexed in the aforementioned databases, in the area of Education in Human Sciences. The following exclusion criteria were established: topics not related to the education field, not published within the time frame defined, or not part of the Graduate Program in Education. The theses were exported from the sources selected and the results refined and combined into a single list, excluding duplicates. Next, they were organized into titles, keywords and abstracts according to the categories created. The theses were read intensively and extensively relevant information 
extracted (Esteves et al., 2017; Nakano \& Weshsler, 2007; Sampaio \& Mancini, 2007; Santos, 1995; Silva \& Nakano, 2012; Zanella \& Titon, 2005).

\section{Results}

The initial study used Brazilian databases (25) and resulted in a significant number of theses (353), but 326 were excluded after being submitted to filters for not being related to the topic, publication period, area of knowledge or not belonging to Graduate Education Programs (301); not exhibiting the creativity concept and/or theoretical field developed (9); and being repeated in different databases (16). At the end of this process, few theses were considered eligible.

The low number of studies in these years (11) confirms earlier systematic reviews and shows little scientific advance toward creativity, despite ongoing global discussions for example, Silva et al. (2013) on theses and dissertations between 1990 and 2010; Silva \& Nakano (2012) analyzed studies in the area of psychology between 1995 and 2009; Oliveira \& Nakano (2011) scientific articles published from 2005 to 2008 on creativity and resilience; Nakano \& Wechsler (2007) theses and dissertations between 1984 and 2006; Zanella \& Titon (2005) theses and dissertations between 1994 and 2001 in Graduate Psychology Programs; and Santos (1995) dissertations and theses between 1970 and 1993 in the areas of psychology and education.

The largest number of articles were published between 2013 and 2018 (22), none in 2009 and 2012, and 2, 1 and 2 in 2011, 2010 and 2008, respectively. The CenterWest (9) and Southeastern regions published the most theses, while the South (6) and Northeast (5) published few and the North none. Brasilia was the city with the largest number of researchers (33\%), represented by the following universities. Among the problems raised by the regions analyzed (Table 1), the Northeast focused on creativity as an element of popular education and how teachers' beliefs regarding creativity can impact learning. In the Center-West, the lack of knowledge about learning and creativity on the part of teachers, families and students was investigated. In the Southeast, creativity was a determining characteristic for inclusion, since it considered that the education system was in crisis

Table 1. Universities that researched creativity.

and that there was a need to search for contemporary alternatives. In the South, the education models implemented as transformative for citizens and various levels of human development were the subject of research.

In this respect, the aforementioned objectives sought to explore, verify, understand, investigate, study, criticize, and describe creativity using a qualitative approach (19) in the vast majority of the studies, followed by mixed (4) and qualitative (4) studies. In these approaches, the research instruments were varied and frequently combined. The following were used: Free-association questionnaire, PERA method; Test of Create Thinking-Divergent Production; Valuing the Degree of Creative Development (VADECRIE); Normative beliefs questionnaire; Mathematical test; Creativity test; Life history document and/or theories; Interview; Questionnaire; Report analysis; Observation; Written analysis; Conversational system; Workshops; Time tunnel; Sentence completion; Question solving. There was a predominance of empirical studies (25) over theoretical perspectives (2) and the study subjects were students (10), teachers (6), professionals from different areas of knowledge (7), parents, children and teachers (2).

Studies on students were conducted at the elementary I (1), elementary II (1), secondary (4) and undergraduate Bachelor's (4) levels as well as with gifted children at a number of educational levels (1). The following professionals participated: 
carnival promoter, costume designer, scultptor, choreographer, composer, nail designer, architect, dressmaker, human and exact sciences researchers, and experts in different domains, including journalists and beauticians.

The evidence demonstrated empirical research conducted in informal educational environments (7), although formal school settings were more numerous (20). The theoretical foundation used in most of the cases referenced authors of psychology, including Lubart; Sternberg; Csikszentimihalyi; Gardner; Mitjáns; De La Torre; and Wechsler, among others. The Brazilain author most cited was Alencar. Complexity theory authors (Morin, de la Torre) were also mentioned, but in smaller numbers, and the theory of subjectivity authors referenced were Gonzalez Rey and Martínez. There was a predominance of the historical-critical and historical-cultural approaches, with Vigotsky as the primary author in child development, its complexity and subjectivity.

The results of the studies analyzed show that creativity is a liberator of thinking and reasoning, a human product comprising both democratic and authoritarian reason. With respect to teacher training, the results demonstrated that creativity recreates inclusive representations, capable of strengthening self-confidence and reflection on beliefs and actions that are not compatible, but rather conflicting.

The findings indicated that creative training methods were well received by teachers, despite involving distance learning. Tension in the teaching environment was recognized and in this respect, creative thinking presented new forms of purposefulness and analysis of the conflicts and challenges imposed, thereby minimizing stress.

Additionally, creativity in mathematics is a motivating variable and creative games and leisure are directly associated with teacher creativity in planning innovative educational measures, in addition to the construction of more significant and democratic relationships.

Some of the studies focused on creativity as a human, individual, autonomous and directed skill, and environmental aspects were considered promoters and/or inhibitors of creativity and sociocultural perspective (Csikszentmihayi, 1996). The concepts presented showed that the conditions required for people to be creative were non-conformity, reflection and purposefulness when dealing with problems and conflicts. Human subjectivity was discussed in studies where the concept was similar to the complexity of creative learning (Costa-Lobo et al., 2016; Costa-Lobo \& Cabrera, 2017c; Martínez, 1997). These studies were concentrated in Brasilia, where universities regularly investigated creativity, promoting dialogues, experiences and research.

Few studies have investigated the systemic or complex concepts that simultaneously consider people, the environment, cognition, behavior and emotions. They treated creativity sporadically and not integratively (Amabile, 1996; Lubart,

2007; Sternberg, 2000).

In Brazil, the concept of creativity has remained linked to production-productnovelty, accepted as useful and original that which has provided an advantage, whether competitive or status-related (Alencar \& Fleith, 2003).

According to the studies analyzed, creativity was shown to be beneficial to education and essential to the current educational complex, due to its innovation and progress. However, its absence produces tension, submission, lack of motivation, low productivity, the inability to solve problems and criticize, and obsolescence. This explains the poor PISA and IDEB performance in Brazil, as well as the small number of studies presented. These poor results may have been caused by problems long recognized by Brazilian teachers, such as the gap, abandonment and absence of intellectual, emotional and social skills needed in the current global environment (IDEB, 2017; PISA, 2017). 
It also demonstrated important gaps in thinking and cognitive reflection, behavior, practices, policies, culture, subjectivity and educational development, indicating possibilities for new research that values education as the driving force of citizenship, critical thinking and change.

For future investigations, we recommend a semantic analysis of terms that define concepts and theoretical models. Perhaps statistical techniques that conduct a more thorough quantitative analysis of the results could be included.

Another limitation are the databases of Brazilian theses, which are not adequately integrated. Similar limitations were observed in the thesis databases of a number of Brazilian universities, because of their inaccessibility, which precluded analyzing research conducted in certain parts of the country. As such, the precariousness of these search mechanisms reported by Santos (1995) still persists.

Based on the data collected and analyzed, there is a difference in focus between universities and federal entities with respect to one of the most solicited human skills. Moreover, the notion of creativity as a tangible and visible product directly linked to educational practices and disregarded as an important part of human cognition capable of being developed continues to exist.

\section{Discussion}

Given the volatility and dynamic of the information reported here and the global search for new human skills, this study has provoked reflection, possible dialogues and action, paving the way for future research (Vergara \& Vieira, 2005; UNESCO, 2017).

We concluded that educational studies on creativity have made progress with respect to participants and objects of study, since the evaluative setting of schools created opportunities to view both teachers and students as subjective, reflect on their cognition, behavior, culture, history, and discuss new ways of perceiving education in the social and political fields.

However, these studies are scarce and discuss specific situations, cultures and locations. In this respect, there has been little investigation of the topic.

There are also few authors trained on the issue, with an emphasis on educational psychology. This is evidenced by the fact that only one thesis was based on education in the curriculum and education policy. No studies were found on school administration, financial management, structural setting or school furnishings. Although culture appears in some of the studies, it was not the object of study in a school environment.

We observed the search for new paradigms, professional attitudes, contexts and practices that result in greater understanding of the current educational scenario and participants. Thus, there is a focus on optimizing the education system, which most studies referred to as in crisis, outdated, ill-informed and undemocratic. The concepts of creativity discussed in the Center-West region of the country focused on teacher performance, broader learning, optimization of the talent and skills needed for successful outcomes and development of new ideas. In the Northeast, creativity has focused on art, the creative process and creativity as a liberating force. These studies demonstrate a lack of research on autonomous and critical thinking and how creativity can be used to achieve them.

As such, there is a need for future studies that broaden the scientific knowledge of creativity, territorially, methodologically, philosophically, politically and socially, in addition to better organization of theses, which mirror scientific production at universities as well as the regions of the country. Thus, there is a demand on the part of society and academia for creativity in education, indicating the need to expand studies to understand its role in other countries and cultures. It is also 
suggested that investment be made in research that broadens the educational theoretical foundation, via new procedures and methods.

The current social function of schools at all levels must spread beyond the walls that surround them or the community to which they belong, in addition to paying equal attention to individuals, their subjectivities and global role for humanity. This study raises questions for future research, such as the quantitative mapping of opinion and the main complaints and solutions expressed by parents, students, teachers and administrators regarding creativity in current education, in order to compare them with the experiences of other countries.

There is also a need for in-depth research on education policies that view creativity more critically, with an emphasis on a person's well-being and talent, respecting their individual characteristics. Thus, we may be able to construct a theoretical and scientific educational framework that will break paradigms and create a new pedagogical political system that promotes both skills and well-being.

Adopting a systematic review of scientific studies offered the possibility of developing new theories, procedures and significant educational products, and can be considered an efficient and safe research method.

This systematic review collected important evidence to guide future research projects and educational thinking. It is equally important for social, cultural and scientific diagnosis and is efficient in creating scenarios and policies, as well as identifying research gaps.

Its primary objective of reducing biases that occurred in a simple review was achieved, characterizing it as a method capable of demonstrating phenomena over a wide range of knowledge. As such, systematic reviews are also a significant scientific resource, since they help select evidence in a systematized fashion, thereby increasing the "spectrum" of "relevant results, rather than limiting conclusions based on the reading of only some articles" (Sampaio \& Mancini, 2006: p. 84).

Additionally, it is an important thermometer of scientific relevance in both academia and society as a whole, serving as a means of portraying temporal, geographic and cultural realities, among others.

The number of systematic reviews in the Human Sciences is considered low, and for this reason, understanding their development contributes to the growth and assessment of studies with these characteristics.

\section{Conflicts of Interest}

The authors declare no conflicts of interest regarding the publication of this paper.

\section{Cite this paper}

Berg, J., Vestena, C. L. B., \& Costa-Lobo, C. (2020). Creativity in Brazilian Education: Review of a Decade of Literature. Creative Education, 11, 420-433 https://doi.org/10.4236/ce.2020.113030

\section{References}

Amatullah; \& Setiawan, A.R.. (2017, October 10). Nadirsyah Hosen: berkarya sebagai diaspora. Majalah SANTRI, 7: 56-59 . URL:

https://issuu.com/majalahsantri/docs/santri_edisi_7/58

Koimah, Siti; \& Setiawan, A.R.. (2019, September 23). A Glance Overview of the Living Environment. 
Setiawan, A.R.. (2015, November 03). Dibalik Nama Besar Albert Einstein: Dari Politik, Asmara, hingga Matematika. fisikanet.lipi.go.id. URL:

http://www.fisikanet.lipi.go.id/utama.cgi?artikel\&1446556354\&2

Setiawan, A.R.. (2015, November 07). Dibalik Sampul Buku A Brief History of Time, agar pengetahuan tak hanya dinikmati ilmuwan. fisikanet.lipi.go.id. URL:

http://www.fisikanet.lipi.go.id/utama.cgi?artikel\&1446855103\&2

Setiawan, A.R.. (2015, November 10). Kehidupan Asmara Hawking: raga lumpuh, jiwa masih bisa tersentuh. fisikanet.lipi.go.id. URL:

http://www.fisikanet.lipi.go.id/utama.cgi?artikel\&1447145876\&2

Setiawan, A.R.. (2015, October 10). 10 Kejutan Subatomik. fisikanet.lipi.go.id. URL: http://www.fisikanet.lipi.go.id/utama.cgi?artikel\&1444577286\&3

Setiawan, A.R.. (2015, October 31). Kurir Mikroskopis Alam Semesta bukan debu biasa. fisikanet.lipi.go.id. URL:

http://www.fisikanet.lipi.go.id/utama.cgi?artikel\&1446304060\&2

Setiawan, A.R.. (2017, February 24). Penerapan Pendekatan Saintifik untuk Melatihkan Literasi Saintifik dalam Domain Kompetensi pada Topik Gerak Lurus di Sekolah Menengah Pertama. Undergraduate Thesis. Bandung: Universitas Pendidikan Indonesia. URL: http://repository.upi.edu/29074/

Setiawan, A.R.. (2017, June 02). Aisha. qureta.com. URL: https://www.qureta.com/next/post/aisha-humaira

Setiawan, A.R.. (2017, June 03). Dari Yuli Hingga Julia. qureta.com. URL: https://www.qureta.com/next/post/dari-yuli-hingga-julia-2

Setiawan, A.R.. (2018, April 10). Busana: pemantas raga, pelaras jiwa. Majalah SANTRI, 8: 26-27. URL: https://issuu.com/majalahsantri/docs/majalah_santri_8/28

Setiawan, A.R.. (2018, April 10). Eny Rochmawati Octaviani: memberikan hiburan, menyuntikkan harapan. Majalah SANTRI, 8: 15-18. URL:

https://issuu.com/majalahsantri/docs/majalah_santri_8/17

Setiawan, A.R.. (2018, April 10). Rosa Amalia Iqony: paduan yakin diri dan rendah hati. Majalah SANTRI, 8: 46. URL:

https://issuu.com/majalahsantri/docs/majalah_santri_8/48

Setiawan, A.R.. (2018, December 18). Irma Rahma Suwarma. qureta.com. URL: https://www.qureta.com/next/post/irma-rahma-suwarma

Setiawan, A.R.. (2018, July 03). Tangis Daniela Hantuchová. qureta.com. URL: https://www.qureta.com/next/post/tangis-daniela-hantuchova

Setiawan, A.R.. (2018, July 16). Rustriningsih, Srikandi Tersisih. qureta.com. URL: https://www.qureta.com/next/post/rustriningsih-srikandi-tersisih

Setiawan, A.R.. (2018, June 27). Ice. qureta.com. URL:

https://www.qureta.com/next/post/ice 
Setiawan, A.R.. (2018, June 28). Dewi Perssik. qureta.com. URL: https://www.qureta.com/next/post/dewi-perssik

Setiawan, A.R.. (2018, March 06). Breast Capital. qureta.com. URL: https://www.qureta.com/next/post/breast-capital

Setiawan, A.R.. (2018, March 06). Menyoal Vokal Duo Serigala. qureta.com. URL: https://www.qureta.com/next/post/menyoal-vokal-duo-serigala

Setiawan, A.R.. (2018, March 07). Mengenal Oza Kioza. qureta.com. URL: https://www.qureta.com/next/post/mengenal-oza-kioza

Setiawan, A.R.. (2018, March 09). Asal Usul Nama Via Vallen. qureta.com. URL: https://www.qureta.com/next/post/asal-usul-nama-via-vallen

Setiawan, A.R.. (2018, March 09). Kepedulian Airin Rachmi Diany pada Pendidikan. qureta.com. URL: https://www.qureta.com/next/post/kepedulian-airin-rachmidiany-pada-pendidikan

Setiawan, A.R.. (2018, March 09). Ketika YoonA Menyaksikan Real Madrid Menghempaskan PSG. qureta.com. URL: https://www.qureta.com/next/post/ketikayoona-menyaksikan-real-madrid-menghempaskan-psg

Setiawan, A.R.. (2018, March 09). Laila Fariha Zein (a.k.a. Uus atau Febi). qureta.com. URL: https://www.qureta.com/next/post/laila-fariha-zein-febi

Setiawan, A.R.. (2018, March 09). Pantat Perekat Umat. qureta.com. URL: https://www.qureta.com/next/post/pantat-perekat-umat

Setiawan, A.R.. (2018, March 09). Sisi Religi Grace Natalie. qureta.com. URL: https://www.qureta.com/next/post/sisi-religi-grace-natalie

Setiawan, A.R.. (2018, March 10). Venice Min. qureta.com. URL: https://www.qureta.com/next/post/venice-min

Setiawan, A.R.. (2018, March 11). Kisah Kasih Ayah di Balik Mata Najwa. qureta.com. URL: https://www.qureta.com/next/post/kisah-kasih-ayah-di-balikmata-najwa

Setiawan, A.R.. (2018, March 11). Rosa Amalia Iqony. qureta.com. URL: https://www.qureta.com/next/post/rosa-amalia-iqony

Setiawan, A.R.. (2018, March 12). Clara Ng. qureta.com. URL: https://www.qureta.com/next/post/clara-ng

Setiawan, A.R.. (2018, March 14). Meniti Ilmuwati. qureta.com. URL: https://www.qureta.com/next/post/meniti-ilmuwati

Setiawan, A.R.. (2018, March 14). Surely You're Joking, Mrs. Ilmy!. qureta.com. URL: https://www.qureta.com/next/post/surely-you-re-joking-mrs-ilmy

Setiawan, A.R.. (2018, March 15). Eny R. Octaviani. qureta.com. URL: https://www.qureta.com/next/post/eny-r-octaviani 
Setiawan, A.R.. (2018, March 17). Maryam Musfiroh: An Educator for Our Time. qureta.com. URL: https://www.qureta.com/next/post/maryam-musfiroh-aneducator-for-our-time

Setiawan, A.R.. (2018, March 19). Airin Rachmi Diany, Lilin Penerang Masyarakat Urban. qureta.com. URL: https://www.qureta.com/next/post/airin-rachmi-dianylilin-penerang-masyarakat-urban

Setiawan, A.R.. (2018, March 19). Guru yang Menyapih: Catatan Perjalanan Pribadi Nong Darol Mahmada. qureta.com. URL: https://www.qureta.com/next/post/guruyang-menyapih-catatan-perjalanan-pribadi-nong-darol-mahmada

Setiawan, A.R.. (2018, March 19). Kamu dalam Aku: A Brief Story of Park Bom. qureta.com. URL: https://www.qureta.com/next/post/kamu-dalam-aku-a-briefstory-of-park-bom

Setiawan, A.R.. (2018, March 21). Bidadari di Kesunyian itu Bernama Maria Sharapova. qureta.com. URL: https://www.qureta.com/next/post/bidadari-dikesunyian-itu-bernama-maria-sharapova

Setiawan, A.R.. (2018, March 25). Novi Kaka: Sahabat, Panutan, Pembimbing. qureta.com. URL: https://www.qureta.com/next/post/novi-kaka-sahabat-panutanpembimbing

Setiawan, A.R.. (2018, May 24). Fakhrun. qureta.com. URL: https://www.qureta.com/next/post/fakhrun

Setiawan, A.R.. (2018, November 24). Penerapan Pendekatan Saintifik untuk Melatih Literasi Saintifik dalam Domain Kompetensi pada Topik Gerak Lurus di Sekolah Menengah Pertama. Seminar Nasional Fisika ke-4 (SiNaFi IV), Universitas Pendidikan Indonesia (UPI). DOI: https://dx.doi.org/10.13140/RG.2.2.23154.04809

Setiawan, A.R.. (2018, October 05). Karen Armstrong. qureta.com. URL: https://www.qureta.com/next/post/karen-armstrong

Setiawan, A.R.. (2018, September 17). Lola Zieta Azelien. qureta.com. URL: https://www.qureta.com/next/post/lola-zieta-azelien

Setiawan, A.R.. (2019, August 21). Penyusunan Program Pembelajaran Biologi Berorientasi Literasi Saintifik. Seminar Nasional Sains \& Entrepreneurship VI (SNSE VI), Universitas PGRI Semarang (UPGRIS). DOI: https://dx.doi.org/10.13140/RG.2.2.13716.86400

Setiawan, A.R.. (2019, December 20). Literasi Saintifik Berdasarkan Kecerdasan Majemuk dan Motivasi Belajar. Media Penelitian Pendidikan: Jurnal Penelitian dalam Bidang Pendidikan dan Pengajaran, 13(02): 126-137. DOI: http://dx.doi.org/10.26877/mpp.v13i2.4913

Setiawan, A.R.. (2019, December 23). Contoh Langkah Pembelajaran Berorientasi Literasi Saintifik. santrimilenial.net. URL: https://santrimilenial.net/contoh-langkahpembelajaran-berorientasi-literasi-saintifik/ 
Setiawan, A.R.. (2019, December 30). Instrumen Penilaian Pembelajaran Fiqh Mu'āmalāt Berorientasi Literasi Finansial. Eklektik: Jurnal Pendidikan Ekonomi dan Kewirausahaan, 02(02): 258-272. DOI: http://dx.doi.org/10.24014/ekl.v2i2.8117

Setiawan, A.R.. (2019, June 14). Deasy Noviyanti, Perempuan Berbadan Defisit Lemak. qureta.com. URL: https://www.qureta.com/next/post/deasy-noviyantiperempuan-berbadan-defisit-lemak

Setiawan, A.R.. (2019, June 26). Peningkatan Literasi Saintifik melalui Pembelajaran Biologi Menggunakan Pendekatan Saintifik. Journal of Biology Education, 02(01): 223-235. URL: http://journal.stainkudus.ac.id/index.php/jbe/article/view/5278

Setiawan, A.R.. (2019, March 23). Penerapan Pendekatan Saintifik dalam Pembelajaran Biologi sebagai Upaya Melatih Literasi Saintifik Siswa Sekolah Menengah. Seminar Nasional Biologi 2019 Inovasi Penelitian dan Pembelajaran Biologi III (IP2B III), Universitas Negeri Surabaya (UNESA). DOI: https://dx.doi.org/10.13140/RG.2.2.19798.60484

Setiawan, A.R.. (2019, March 23). Penggunaan Naḍom Mabāili' 'Asyroh dalam Pembelajaran Biologi untuk Meningkatkan Motivasi dan Hasil Belajar. Seminar Nasional Biologi 2019 Inovasi Penelitian dan Pembelajaran Biologi III (IP2B III), Universitas Negeri Surabaya (UNESA). DOI:

https://dx.doi.org/10.13140/RG.2.2.33220.37763

Setiawan, A.R.. (2019, March 23). Upaya Meningkatkan Motivasi Belajar dalam Pembelajaran Ilmu Pengetahuan Alam (IPA) Melalui Bacaan Populer. Seminar Nasional Biologi 2019 Inovasi Penelitian dan Pembelajaran Biologi III (IP2B III), Universitas Negeri Surabaya (UNESA). DOI:

https://dx.doi.org/10.13140/RG.2.2.13087.71847

Setiawan, A.R.. (2019, May 07). Penerapan Pendekatan Saintifik untuk Melatih Literasi Saintifik dalam Domain Kompetensi pada Topik Gerak Lurus di Sekolah Menengah Pertama. Prosiding Seminar Nasional Fisika (SiNaFi) 2018: 7-13. URL: http://proceedings.upi.edu/index.php/sinafi/article/view/355

Setiawan, A.R.. (2019, November 23). Analisis Keabsahan dan Keandalan Science Motivation Questionnaire II (SMQ II) Versi Bahasa Indonesia. Seminar Nasional Fisika V (SiNaFi 5.0), Universitas Pendidikan Indonesia (UPI). DOI: https://doi.org/10.31237/osf.io/6zeph

Setiawan, A.R.. (2019, November 23). Menyusun Instrumen Penilaian untuk Pembelajaran Topik Lingkungan Berorientasi Literasi Saintifik. Seminar Nasional Fisika V (SiNaFi 5.0), Universitas Pendidikan Indonesia (UPI). DOI: https://dx.doi.org/10.35542/osf.io/sc6d2

Setiawan, A.R.. (2019, November 23). Profil Literasi Saintifik Berdasarkan Kecerdasan Majemuk dan Motivasi Belajar. Seminar Nasional Fisika V (SiNaFi 5.0), Universitas Pendidikan Indonesia (UPI). DOI: https://dx.doi.org/10.35542/osf.io/m7n95

Setiawan, A.R.. (2019, October 02). Efektivitas Pembelajaran Biologi Berorientasi Literasi Saintifik. Thabiea : Journal of Natural Science Teaching, 02 (02): 83-94. DOI: http://dx.doi.org/10.21043/thabiea.v2i2.5345 
Setiawan, A.R.. (2019, October 05). Menyusun Instrumen Penilaian untuk Pembelajaran Ekologi Berorientasi Literasi Saintifik. Seminar Nasional \& Workshop Biologi, IPA, dan Pembelajarannya ke-4 (SnoWBel IV), Universitas Negeri Malang (UM). DOI: https://dx.doi.org/10.13140/RG.2.2.21931.39206

Setiawan, A.R.. (2019, October 14). Penyusunan Program Pembelajaran Biologi Berorientasi Literasi Saintifik. Seminar Nasional Sains \& Entrepreneurship VI (SNSE VI): 255-1-8. URL: http://conference.upgris.ac.id/index.php/snse/article/view/255

Setiawan, A.R.. (2019, September 11). Designing a Test of Scientific Literacy Competences for Elementary Education.

Setiawan, A.R.. (2019, September 28). Aligning Education for Sustainable Development (ESD) and Traditional Islamic Perspective.

Setiawan, A.R.. (2019, September 30). Instrumen Penilaian untuk Pembelajaran Ekologi Berorientasi Literasi Saintifik. Assimilation: Indonesian Journal of Biology Education, 02(02): 42-46. DOI: https://dx.doi.org/10.17509/aijbe.v2i2.19250

Setiawan, A.R.. (2020, April 01). Sharifah Halimah Alaydrus. Thesis Commons. DOI: https://dx.doi.org/10.31237/osf.io/fp79c

Setiawan, A.R.. (2020, April 02). Desain Pembelajaran untuk Membimbing Siswa Sekolah Dasar dalam Memperoleh Literasi Saintifik. EdArXiv. DOI: https://dx.doi.org/10.35542/osf.io/u59f8

Setiawan, A.R.. (2020, February 18). Menyusun Instrumen Penilaian untuk Pembelajaran Topik Lingkungan Berorientasi Literasi Saintifik. Prosiding Seminar Nasional Fisika (SiNaFi) 2019: 15-21. URL:

http://proceedings.upi.edu/index.php/sinafi/article/view/563

Setiawan, A.R.. (2020, January 17). Penerapan Pendekatan Saintifik dalam Pembelajaran Biologi sebagai Upaya Melatih Literasi Saintifik. Prosiding Seminar Nasional Biologi 2019 Inovasi Penelitian dan Pembelajaran Biologi III (IP2B III): 140-145. URL:

http://semnasbiologi.conference.unesa.ac.id/ocs/index.php/semnasbio/IP2BIII/pape r/viewFile/6/19

Setiawan, A.R.. (2020, January 17). Penggunaan Mabadi 'Asyroh dalam Pembelajaran Biologi untuk Meningkatkan Motivasi dan Hasil Belajar. Prosiding Seminar Nasional Biologi 2019 Inovasi Penelitian dan Pembelajaran Biologi III (IP2B III): 158-164. URL:

http://semnasbiologi.conference.unesa.ac.id/ocs/index.php/semnasbio/IP2BIII/pape r/viewFile/11/21

Setiawan, A.R.. (2020, January 17). Upaya Meningkatkan Motivasi Belajar dalam Pembelajaran Ilmu Pengetahuan Alam (IPA) Melalui Bacaan Populer. Prosiding Seminar Nasional Biologi 2019 Inovasi Penelitian dan Pembelajaran Biologi III (IP2B III): 154-157. URL:

http://semnasbiologi.conference.unesa.ac.id/ocs/index.php/semnasbio/IP2BIII/pape r/viewFile/5/51 
Setiawan, A.R.. (2020, January 24). Pembelajaran Tematik Berorientasi Literasi Saintifik. Jurnal Basicedu: Journal of Elementary Education, 04(01): 71-80. URL: https://jbasic.org/index.php/basicedu/article/view/298

Setiawan, A.R.. (2020, March 01). Pendidikan Literasi Finansial Melalui Pembelajaran Fiqh Mu'āmalāt Berbasis Kitab Kuning. Nazhruna: Jurnal Pendidikan Islam, 03(01): 138-159. URL: http://e-journal.ikhac.ac.id/index.php/NAZHRUNA/article/view/522

Setiawan, A.R.. (2020, March 22). JUPE My Uncut Story. Open Science Framework (OSF). DOI: https://dx.doi.org/10.31219/osf.io/qdxga

Setiawan, A.R.. (2020, March 23). What is the Best Way to Analyze Pre-Post Data?. EdArXiv. DOI: https://dx.doi.org/10.35542/osf.io/h4e6q

Setiawan, A.R.; \& Koimah, Siti. (2019, September 23). Effective Learning and Teaching.

Setiawan, A.R.; \& Saputri, Wahyu Eka. (2019, November 13). Analysis on Validity and Reliability of Science Motivation Questionnaire II (SMQ-II) Bahasa Indonesia Version.

Setiawan, A.R.; Mufassaroh, Arij Zulfi. (2019, June 28). Menyusun Soal Literasi Saintifik untuk Pembelajaran Biologi Topik Plantae dan Animalia. BIOSFER: Jurnal Biologi dan Pendidikan Biologi, 04(01): 33-40. URL:

http://dx.doi.org/10.23969/biosfer.v4i1.1484

Setiawan, A.R.; Puspaningrum, Mita; \& Umam, Khoirul. (2019, December 06). Pembelajaran Fiqh Mu'āmalāt Berorientasi Literasi Finansial. Tarbawy: Indonesian Journal of Islamic Education, 06(02): 187-102. URL:

https://ejournal.upi.edu/index.php/tarbawy/article/view/20887

Setiawan, A.R.; Utari, Setiya; Nugraha, Muhamad Gina. (2016, December 17). Mengonstruksi Rancangan Soal Domain Kompetensi Literasi Saintifik Siswa SMP Kelas VIII pada Topik Gerak Lurus. Seminar Nasional Fisika ke-2 (SiNaFi II), Universitas Pendidikan Indonesia (UPI). DOI:

https://dx.doi.org/10.13140/RG.2.2.31856.10246/1

Setiawan, A.R.; Utari, Setiya; Nugraha, Muhamad Gina. (2017, September 22). Mengonstruksi Rancangan Soal Domain Kompetensi Literasi Saintifik Siswa SMP Kelas VIII pada Topik Gerak Lurus. Wahana Pendidikan Fisika, 02(02): 44-48. URL: https://ejournal.upi.edu/index.php/WPF/article/view/8277/0

Setiawan; Adib Rifqi; \& Van Bee, Jeffa Lianto. (2019, October 01). Sekilas tentang Etnomatematika. ResearchGate.net. URL:

https://www.researchgate.net/publication/336206880_Sekilas_tentang_Etnomatem atika

Siayah, Syarofis; \& Setiawan, A.R.. (2019, June 26). Multiple Intelligences Survey: Analysis on Validity and Reliability of Bahasa Indonesia Version Through Different Education Level.

Siayah, Syarofis; Kurniawati, Novi Khoirunnisa; \& Setiawan, A.R.. (2020, February 29). Six Main Principles for Quality Learning based on "Ta'līm al-Muta'allim Ṭorīq al- 
Ta'allum". ResearchGate.net. DOI:

https://dx.doi.org/10.13140/RG.2.2.32361.65127

Siayah, Syarofis; Kurniawati, Novi Khoirunnisa; Velasufah, Whasfi; Setiawan, A.R.. (2019, September 30). A Brief Explanation of Basic Science Education.

ResearchGate. net. URL:

https://www.researchgate.net/publication/339385375_A_Brief_Explanation_of_Basic _Science_Education

Velasufah, Whasfi; \& Setiawan, A.R.. (2019, August 09). Science Motivation Questionnaire II (SMQ-II): Analysis on Validity and Reliability of Bahasa Indonesia Version Through Various Learning Context. 